\title{
Triadic Family Interactions in the Context of Bodily-Self Development
}

\section{Тріадні взаємовідносини в родині у контексті розвитку тілесного Я}

\section{Daria Turkova}

Ph.D in Psychology, Doctoral Student of Practical Psychology Department, H. S. Skovoroda Kharkiv National Pedagogical University, Kharkiv (Ukraine)

ORCID ID: https://orcid.org/0000-0002-3788-1185

E-mail: tdariamail@gmail.com

\section{Дар'я Туркова}

Кандидат психологічних наук, докторант кафедри практичної психології, Харківський національний педагогічний університет імені Г. С. Сковороди, м. Харків (Україна)

\section{ABSTRACT}

In the article we provide the analytical review of psychological researches concerning family's structure with triadic and dyadic interactions in the context of bodily-self development. The father's role is determined in psychological development of a child. The list of psychological indexes of child's development influenced by father's presence or deprivation of him is given. The descriptions of a family functioning since time of a child appearance are given. Optimal operating of family conditions is determined for healthy development of a child and bodily-self development.

The aim of the article is systematization of the theoretical and applied principles in relation to understanding of psychological sense of triad in the

Address for correspondence, e-mail: kpnu_lab_ps@ukr.net Copyright: (C) Turkova Daria

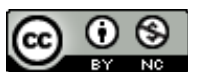

(C) Turkova Daria 
context of bodily-self development. The main method of the research was the theoretical analysis of scientific literature, that gave an opportunity to find out the role of the triad of "father-mother-child» at bodily-self development of a child.

The results of the research gave an opportunity to define the equal role in rights of father in relation to a mother at the education of a child. The psychological features of a child's development were also defined, that needed a father. Optimal conditions of triadic functioning in family are found out for the sake of bodily-self development.

Conclusions. The triad means the system of "father - mother - child", functioning according to the laws of the theory of family systems. A child's bodilyself development is laid in childhood at the perinatal stage of development in the context of forming the dyad of "mother - child» relation. The birth of a child brings family over to the next stress period, the successful overcoming of that must create the triadic mutual relations with the new roles of father and mother, married couple does not lose an intimate contact with each other as a man and woman. At all stages of a family functioning, including the period of pregnancy and in future the role of a father for harmonious child's development and bodilyself is important and irreplaceable. The dyad of "mother - child» is equivalent to the "father - child» dyad, in case of granting the possibility of paternal attaching to the process of care and education of a child.

Key words: triadic interaction, dyadic interaction, fatherhood, family system, bodily-self development.

\section{Вступ}

Говорячи про розвиток тілесного Я в межах родини як одного з інститутів соціалізації, постає питання розуміння самої родини як єдиного цілісного утворення чи комбінації взаємовідносин між її членами. Коли мова йде про дитину, зазвичай, розвиток її особистості розглядають у контексті взаємовідносин із референтною особою, себто матір'ю. Проте, виходячи з розуміння родини як цілісної системи, маємо необхідність зосередити нашу увагу і на взаємовідносинах із батьком. Вивчаючи розвиток тілесного Я в повній нуклеарній родині з акцентом на діадах «мати - дитина» чи «батько - дитина», таке виокремлення залишає одного з батьків

(C) Turkova Daria

DOI (article): https://doi.org/10.32626/2227-6246.2020-49.342-362 
DOI: https://doi.org/10.32626/2227-6246.2020-49

на периферії відносин, хоча йдеться про всю родину загалом, тому доречно зосередитися на тріаді.

Варто звернути увагу, що у деяких публікаціях тріада вказується у послідовності «мати - дитина - батько», «мати - батько - дитина» або «батько - мати - дитина». Для вітчизняних робіт більш характерна послідовність «мати - дитина - батько», а для західних - «мати - батько - дитина». Щодо цього можемо зробити кілька припущень: 1) тріада є цілісною системою, тому не має значення послідовність об'єктів у ній, адже всі вони рівнозначні; 2) виникненню цілісної тріади передує діада, тому послідовність є важливою. У такому разі можемо розглянути два варіанти: 2.1) до сформованої діади «мати - дитина» додається батько; 2.2) діада з подружньої пари долучає до своїх уже створених взаємин дитину. На нашу думку, оптимальною умовою для розвитку тілесного Я та функціонування родини загалом є варіант 2.2 за умови розуміння тріади як системи, що $є$ рідкісним явищем для слов'янського типу родин.

Відтак, метою публікації $є$ систематизація теоретико-прикладних положень щодо розуміння психологічного сенсу тріади у контексті розвитку тілесного Я.

\section{Завдання статті}

Визначити психологічні особливості тріадних взаємовідносин стосовно діадних, що функціонують у родинах у контексті розвитку тілесного Я.

\section{Методи та методики дослідження}

У дослідженні використано теоретичний аналіз наукової літератури, що дало змогу з'ясувати роль тріади «батько мати - дитина» у розвитку тілесного Я дитини.

\section{Результати та дискусії}

У дослідженні K. А. Levin i C. Currie (Levin \& Currie, 2010) було виявлено зв'язок між спілкуванням систем (C) Turkova Daria

DOI (article): https://doi.org/10.32626/2227-6246.2020-49.342-362 
«мати - дитина» $\mathrm{i}$ «батько - дитина» й задоволеністю життям молоді. Розглядаючи два підходи щодо розуміння благополуччя (еудемонічний - у який люди функціонують у житті та гедонічний - спосіб, у який вони сприймають своє життя), автори пояснюють задоволення життям як міру гедонісу (добробуту), що є показником i психічного благополуччя зокрема. Автори особливо наголошують на важливості стосунків матері й дівчинки. Хлопці, які не проживали у повній нуклеарній родині, мали низький рівень задоволеності життям, навіть коли спілкування з одним із батьків було легким і це явище не залежало від економічного стану родини.

Вивчаючи відмінності між тріадичною взаємодією «мати - батько - дитина» й діадичною - «мати - дитина», E. W. Lindsey та Y. M. Caldera (Lindsey \& Caldera, 2006) виявили, що матері менш включені й негативні при тріадичній взаємодії, ніж при діадичній. У тріаді матері синів демонстрували більше емоційності, ніж матері дочок, окрім того, матері були більш включені, ніж батьки. Батьки більше підтримували матерів, а матері були більш настирливі стосовно батьків упродовж тріадних взаємовідносин. На гіпотетичному етапі підсумків з отриманих даних теоретичного аналізу літератури автори також зазначили, що у діадних відносинах мати більш включена, емоційна і сензитивна. Проте автори звертають нашу увагу на нестачу даних про взаємини у системі «батько - дитина», адже таких досліджень не було проведено.

N. Favez, F. Frascarolo та H. Tissot указують, що в історичному плані першочергово велися дослідження системи «мати - дитина» і лише потім почали вивчати систему «батько - дитина», оскільки вважалося, що батько здійснював лише дистальний вплив на розвиток немовляти. Із соціальними змінами західних суспільств наприкінці 1960-х на початку 1970-х рр. виникло покоління «нових батьків», які почали брати на себе обов'язки з догляду за своїми діть-

(C) Turkova Daria

DOI (article): https://doi.org/10.32626/2227-6246.2020-49.342-362 
DOI: https://doi.org/10.32626/2227-6246.2020-49

ми. Після цих змін численні дослідження були присвячені розвитку відносин «батько - дитина», повторюючи протоколи, які використовувалися у дослідженнях стосунків «мати - дитина». Результати показали схожість між матерями та батьками у здатності розуміти емоційні сигнали своїх дітей, крім того, взаємодія «батько - немовля» аналогічна взаємодії «мати - немовля», але з відмінностями в бажаних темах взаємодій: батьки більш схильні використовувати фізичну гру і бути непередбачуваними у своїх стимулах щодо дитини. Також було з'ясовано, що батькова психопатологія також негативно впливає на розвиток дитини (Favez, Frascarolo \& Tissot, 2017). Результати цих досліджень показали, що обидва батьки є важливими партнерами для дитини, що висунуло на перший план питання про координацію між матір'ю та батьком щодо їх відповідних переконань й очікувань щодо батьківства, а також їх щоденної взаємодії з немовлям. У зв'язку з цим емпіричні дані свідчать про справжній ефект, коли сім'я взаємодіє як тріада (Favez, Frascarolo \& Tissot, 2017).

Iз цього приводу спостереження N. Favez i F. Frascarolo надають дані, що якщо традиційні оцінки стосунків «мати дитина» (та «батько - дитина») залишаються важливими у практиці раннього втручання, то вони повинні бути відмежовані й доповнені оцінкою тріадних відносин; насправді на самі діади, а не тільки на дитину, впливає тріадний контекст. Кілька досліджень показали, що діади «мати - дитина» чи «батько - дитина» взаємодіють по-різному, коли їх оцінюють поодинці або в присутності іншого з батьків. Отже, тріадна оцінка в рамках системних консультацій виявилася дуже багатим і доповнюючим інструментом для діадичних оцінок з метою орієнтування та керівництва втручанням (Favez \& Frascarolo, 2011).

Вивчаючи розвиток тріадичних взаємодій у системі «мати - батько - дитина», N. Favez i F. Frascarolo (Favez \& Frascarolo, 2011) концептуалізують тріадні відно(C) Turkova Daria

DOI (article): https://doi.org/10.32626/2227-6246.2020-49.342-362 
сини з точки зору «сімейного союзу», а саме: здатності сім'ї виконувати командні завдання. Основна передумова підходу N. Favez i F. Frascarolo полягає в тому, що сімейний союз відіграє роль соціального навчального контексту для дитини. Альянс буде «функціональним», коли партнери зможуть скоординуватися у більшості ситуацій і коли емоції будуть здебільшого позитивні та доброзичливі, тоді як він буде «дисфункціональним», коли координація систематично складна (або й неможлива) у зв'язку з конфліктом між батьками або виключенням одного з батьків із тристоронніх стосунків, а взаємодії повторюються холодно і віддалено. На думку авторів, кілька досліджень, проведених у клінічних і дослідницьких умовах, показали вплив якості взаємовідносин спільного батьківства і тим самим тріадну динаміку реляції на розвиток дитини. У цьому контексті вони згадують роботи С. Мінухіна, які продемонстрували, як дитина може бути «тріангульованою» між їі батьками і розвивати симптом, що дає змогу відволікти їх від конфлікту.

Колектив авторів (Venturelli, Cabrini, Fruggeri \& Cigala, 2016) надає аналітичний огляд 26 досліджень, присвячених тріадній взаємодії «мати - батько - дитина» за допомогою спостережувальних процедур. Автори дійшли висновку, що навіть якщо всі розглянуті дослідження були покликані проаналізувати тріади, дуже мало використано цілісно тріадичних категорій: більшість із них зосереджувалися на окремих членах тріади або на батьках стосовно дитини. На думку авторів, варто зосередити увагу саме на тріаді (взаємодії всіх її членів).

Визнання важливості тріадного рівня відбулося також унаслідок досліджень, які показали вплив на дитину взаємовідносин батьків: на розвиток дитини впливає співпраця та конфлікт між батьками. Ця співпраця або ї̈ відсутність осмислювались як співпрацюючі стосунки - тобто, батьки підтримували один одного чи ні, у своїх стосунках із дитиною на інструментальному й емоційному рівнях. N. Favez, (C) Turkova Daria DOI (article): https://doi.org/10.32626/2227-6246.2020-49.342-362 
DOI: https://doi.org/10.32626/2227-6246.2020-49 2020. випуск 49

F. Frascarolo та H. Tissot було виявлено, що кожен партнер здійснює вагомий внесок у сімейну взаємодію, включаючи немовля. Більш того, навіть коли один із батьків не активний у взаємодії, достатньо лише його присутності для внесення модифікацій у взаємодію іншого батька з дитиною (Favez, Frascarolo \& Tissot, 2017).

N. Favez i F. Frascarolo (Favez \& Frascarolo, 2011) 3oceредили увагу на спостереженні за невербальним обміном із трьома людьми, щоб запропонувати підхід, який ураховує всіх партнерів у взаємодії, включаючи дитину. Вони ставили за мету: описати еволюцію сімейного союзу впродовж перших років; визначити чинники, що пояснюють розвиток функціонального чи дисфункціонального союзу; оцінити наслідки впливу якості союзу на емоційно-пізнавальний розвиток дитини. Результати цього дослідження показують, що сімейна тріада, якість взаємодії якої оцінювали дослідники з точки зору сімейного союзу, встановлюється дуже рано ще до народження першої дитини, ймовірно, залежно від конституції альянсу під час вагітності. Тоді він є відносно стабільним, оскільки для більшості сімей ресурси і труднощі, які спостерігаються під час вагітності, залишаються подібними впродовж перших двох років життя дитини. Для невеликої кількості з них альянс погіршується між третім і дев'ятим місяцями. Ці різні траєкторії, що мають різні передумови і наслідки для розвитку дитини, автори узагальнюють таким чином: високий і стійкий альянс сприяє розвитку розуміння психічних станів і захищає проти порушень поведінки. Погіршення альянсу не має наслідків для когнітивного розвитку, але відзначається емоційним негативом, який проявляється в поведінкових розладах і конфліктному уявленні про сімейні стосунки. Низький і стабільний союз відрізняється «порожністю», меншою працездатністю у розумінні психічних станів у дітей, а також відносно низькою симптоматикою погіршення поведінки.

(C) Turkova Daria

DOI (article): https://doi.org/10.32626/2227-6246.2020-49.342-362 
N. Favez i F. Frascarolo наводять кілька клінічних наслідків, що випливають із цих результатів. По-перше, наявність зв'язку між тріадними взаємодіями та кількома змінними, що стосуються емоційно-когнітивного розвитку дитини, свідчить про те, що тріадичну динаміку слід приймати і враховувати для повнішого розуміння реляційного контексту, який впливає на майбутнє дитини. Тоді відносно неглибокі зв'язки альянсу з реляційними змінними діадного рівня (суміжне задоволення, прихильність у діаді «мати - дитина») показують, що тріадні взаємодії уможливлюють інший рівень реляційних змінних сім’ї (Favez \& Frascarolo, 2011).

У зазначеному контексті варто згадати теорію сімейних систем. Г. Я. Варга наголошує, що положення «Ціле більше, ніж сума його частин» у системній теорії складає основу принципу тотальності, або нон-сумарності. Закони функціонування системи не зводяться до суми законів функціонування її підсистем (елементів, об’єктів). Система якісно відрізняється від своїх елементів і їх сукупності. Усі частини і процеси цілого взаємовпливають і взаємообумовлюють один одного. У системному підході лінійна причинно-наслідкова логіка існувати не може, вона замінюється на кругову логіку, в якій головне запитання «Навіщо?» Для того, щоб виявити психодинаміку сімейного життя, необхідно перейти до системного мислення. Елементи системи пов'язані один 3 одним через будь-яку взаємодію, і будь-яка взаємодія несе інформацію системі як про окремі елементи, так і про усю систему загалом (Варга, 2011).

Описуючи життєвий цикл родини за 8 стадіями, Г. Я. Варга (Варга, 2011) зазначає, що перша стадія - монади - після одруження змінюється діадою, на яку припадає перша криза, коли люди починають жити разом і мають домовитися, за якими правилами відбуватиметься спільне життя. Фактично, мова йде про взаємовідносини чоловіка і жінки. 3 появою дитини подружжя переходить до стадії тріади і нової кризи (ми не зупинятимемося на мотивах на-

(C) Turkova Daria

DOI (article): https://doi.org/10.32626/2227-6246.2020-49.342-362 
родження дитини, що є вкрай важливим для аналізу мікроклімату родини, проте нас цікавить лише структура родини). Г. Я. Варга називає це структурною кризою родини, за якої виникає відчуття, що подружжя віддалилося один від одного, часто чоловік говорить, що почувається самотньо, покинуто, занедбано, адже дружина займається або своєю вагітністю, або своєю дитиною. Настає пік подружніх зрад, а також потреба передомовлятися, оскільки функції й обов'язки в родині мають змінитися. На думку Варги, поява дитини збільшує дистанцію між подружньою парою (мати дитина - батько), але робить сімейну структуру стійкішою.

Є. В. Фісун, узагальнюючи досвід Дж. Брауна, Д. Крістенсен, С. Мінухіна й Ч. Фішмана, зазначає, що подружня підсистема, співпадаючи за своїм складом із батьківською, має інші завдання і функції та включає тільки патерни трансакцій, пов'язані з проявом уваги один до одного, але не до дітей. Останні стереотипи взаємодії є функцією батьківської підсистеми. Одним із життєво важливих завдань подружньої підсистеми є вироблення кордонів, які захищають кожного з подружжя, залишаючи йому територію, необхідну для задоволення власних психологічних потреб без втручання родичів, дітей та інших членів сім'ї. Адекватність таких кордонів - один із найважливіших аспектів життєздатності сімейної структури (Фисун, 2017).

М. М. Володін і П. І. Сидоров стверджують, що головні зміни у взаємовідносинах подружньої пари настають саме після народження дитини. Навіть коли дитина є улюбленою та бажаною, вона порушує подружні взаємини між чоловіком і жінкою, подружжя має надати пріоритет відновленню інтимних взаємин, які були до її народження.

Ігнорування подружніх взаємовідносин призводить до того, що один із батьків, а іноді й обидва, вважають себе відсунутими на другий план через дитину (Володин \& Сидоров, 2009: 81).

(C) Turkova Daria

DOI (article): https://doi.org/10.32626/2227-6246.2020-49.342-362 
Посилаючись на дослідження М. Малер, автори (Володин \& Сидоров, 2009: 83) говорять, що діада «мати - дитина» виникає раніше, ніж тріада, проте дослідження Редхольм і Ларсен, у якому через 15 хвилин після народження дитину передавали притиснути до тіла батька, показало виникнення ідентичних реакцій між батьком і дитиною, як це було у варіанті «мати - дитина». Отже, автори підтвердили очевидний для психологів факт, що роль батька у взаємовідносинах із дітьми нічим не замінна: дослідження Р. Парке показало, що діти, яких батько допомагав пеленати, купати, годувати, виявляються терплячішими до присутності незнайомої людини; з раннього дитинства спостерігаються відмінності у взаємовідносинах дитини з батьком і матір'ю: за доглядом і пестощами діти йдуть до матері, погратися - до батька; дивлячись на матір, дитина частіше посміхається, а на батька - сміється.

Г. Я. Варга (Варга, 2011), згадуючи дослідження С. Miнухіна, у своїй роботі стверджує, що він багато працював із бідними негритянськими родинами і так званими «жіночими сім'ями»: мати і діти - у центрі сім'ї, батько - на периферії: він або алкоголік, або наркоман, або десь пропадає. Така структура склалася не випадково: за часів рабства було не прийнято зберігати і культивувати сімейні зв'язки рабів. Чорношкірого раба використовували як виробника, у нього були жінки і діти, але не було сім’ї. Роль чоловіка і батька була принижена, в популяції вона досі не відновлена. С. Miнухін створив цілу систему включення периферійного батька в сім'ю і вибудовування здорової подружньої коаліції. Учений посилював подружні зв'язки, підвищував внутрішньосімейний статус батька, його авторитет, змінюючи тим самим структуру сімейної системи.

Отже, маючи за методологічну основу вищезазначене, ми виходимо з позиції, що тріада є системою і складається 3 чоловіка і дружини (які виконують роль батька і матері) та дитини. У перинатальний період і період немовлячого віку

(C) Turkova Daria

DOI (article): https://doi.org/10.32626/2227-6246.2020-49.342-362 
DOI: https://doi.org/10.32626/2227-6246.2020-49 2020. випуск 49 об’єктивно діадичні взаємини матері та дитини ближчі, ніж взаємини батька і дитини. Відповідно, говорячи про тріаду, ми говоримо «батько - мати - дитина» і взаємини між ними діють за законами теорії сімейних систем.

Порушуючи проблему формування психосоматичної компетентності в психологічному консультуванні подружніх пар, К. В. Седих (Седих, 2017) відзначає негативний вплив подружніх конфліктів на соматичне здоров'я партнерів. Причому, подружню пару дослідниця розглядає як окрему систему (підсистему) ширшої системи - нуклеарної сім'ї (родини), а психосоматичний прояв - як симптом (проблему), що виникає саме у взаємодії і є породженням цієї взаємодії.

Так, у дослідженні колективу авторів (Simonelli, Parolin, Sacchi, De Palo \& Vieno, 2016) вивчався вплив подружніх стосунків та участі батька в догляді за дітьми на тенденцію розвитку якості взаємодії «мати - батько - дитина». На думку авторів, подружні стосунки прийнято вважати найважливішими сімейними підсистемами, створюючи основу для емоційно-реляційного функціонування всієї родини та впливаючи на сімейні взаємодії під час переходу до батьківства. Подружнє задоволення мислиться як конструкція, що підлягає змінам, із певними траєкторіями з часом, відповідно до різних переходів розвитку в життєвому циклі сім’ї. Результати показали, що сімейні взаємодії зростають із часом, а зниження подружньої адаптації пов'язане з поліпшенням якості сімейних взаємодій. Автори підкреслюють, що участь батька прогнозує якість сімейних взаємодій із найраніших стадій життя дитини. У довгостроковій перспективі сімейні взаємодії та якість подружжя демонструють протилежні тенденції розвитку, а участь батька $є$ особливо важливою рисою сім’ї.

Для хлопчиків, які зростають без батька, у подальшому житті властиві проблеми у сферах статевої ролі та розвитку статевої ідентичності. Також відсутність батька в родині (C) Turkova Daria

DOI (article): https://doi.org/10.32626/2227-6246.2020-49.342-362 
призводить до проблем не лише економічного і соціального спектра, а й психоемоційного розвитку дитини (Cabrera, Tamis-LeMonda, Bradley, Hofferth \& Lamb, 2000).

Вивчаючи особливості образу тіла у дітей старшого дошкільного віку, які виховуються в умовах батьківської депривації в різні періоди дитинства, Н. М. Горшкова (Горшкова, 2013) дійшла до таких висновків:

1. Існує зв'язок між порушенням образу тіла в дошкільному віці й досвідом батьківської депривації. Образ тіла дітей, які виховуються в умовах батьківської депривації, має низку особливостей, що відрізняють їх від дітей із повних сімей.

2. Існує зв'язок між особливостями образу тіла дітей і періодом дитинства, впродовж якого дитина виховувалася без батька.

3. Кордони образу тіла дітей, які виховуються без батька, характеризуються слабкою диференціацією, нестійкістю, акцентуацією на бар'єрній функції.

4. Образ тіла дітей, які виховуються без батька упродовж дитячого і раннього віку, найбільшою мірою відрізняється від образу тіла дітей, які виховуються у повних сім'ях.

Результати дослідження Н. М. Горшкової у співавторстві з О. В. Філіповою (Горшкова \& Филиппова, 2013) поглибили уявлення про шкоду, завдану відсутністю батька при вихованні дитини, а саме про негативний вплив на образ тіла. Отже, дослідження образу тіла у дітей, які виховуються без батька в різні періоди дитинства, дало авторам підстави говорити про певні особливості образу тіла.

1. Для дітей, які виховуються без батька з народження (тільки матір'ю), характерні нестійкість і проникність тілесних кордонів, порушення уявлень про себе в тимчасовій перспективі, порушення координації головних вимірів образу тіла (симетрії й інтеграції), слабкий зв’язок між сферою контролю і сферою потягів, тобто регуляція тілесних функцій не сформована.

(C) Turkova Daria

DOI (article): https://doi.org/10.32626/2227-6246.2020-49.342-362 
DOI: https://doi.org/10.32626/2227-6246.2020-49 2020. випУск 49

2. Для дітей, які виховуються без батька в дитячому i ранньому віці, характерні порушення уявлень про себе в тимчасовій перспективі та цілісності тілесних кордонів; бар'єрна функція кордонів акцентуйована; часто зустрічаються вихід за свої тілесні кордони, відторгнення, проектування частини себе зовні; цим дітям властива також така стратегія побудови контакту зі світом, як уникнення контактів.

3. Для дітей, які виховуються без батька з трьох років, характерні порушення цілісності тілесних кордонів, акцентуація на функції бар'єрності кордонів.

Отримані результати Н. М. Горшкова й О. В. Філіпова розглядають як підтвердження теоретичних положень, існуючих у психології, про роль батька в психічному розвитку дитини. Їх результати дають уявлення про неявні тілесні зміни в образі $Я$ дітей, які виховуються без батька в різні періоди дитинства.

Багато років досліджуючи й аналізуючи психологічні напрацювання з проблеми визначення ролі батька в розвитку дитини, M. E. Lamb (Lamb, 2010) виокремив три важливі чинники впливу: 1) доступність (фізична присутність), навіть якщо він безпосередньо не бере участь у спільній діяльності з дитиною; 2) відповідальність за прийняття рішень щодо догляду за дітьми, охорони здоров'я й освіти; 3) залученість, що включає пряму взаємодію батька та дитини в ігрових ситуаціях і щоденному догляді.

Зазначені вище дані не суперечать і конкретизуються у результатах наших особистих досліджень (Туркова, 2019; Туркова \& Ляса, 2019). Так, нами вивчався якісний вплив особистості матері та батька на тілесне Я дитини, а також у контексті вивчення розвитку тілесного Я дитини молодшого шкільного і підліткового віку. В якості предиктора було визначено психологічну відстань між батьками та дитиною. Виявилося, що чим більша психологічна відстань у дитини молодшого шкільного віку з матір'ю, тим краще у неї роз(C) Turkova Daria

DOI (article): https://doi.org/10.32626/2227-6246.2020-49.342-362 
винена здатність до суб’єкт-суб'єктної внутрішньої комунікації та взаємодії з тілесним Я. I навпаки, чим ближче дитина до матері, тим гірше проявляється суб'єктивність. Чим ближчою психологічно є дитина до батька, тим краще у неї розвинена здатність фіксувати і концентрувати увагу на внутрішніх відчуттях, що проявляється у їх диференційованій вербалізації. I навпаки, збільшення відстані погіршують показники інтрацептивності у дитини. Також нами було виявлено, що для дитини немає суттєвої різниці у психологічному впливі окремо батька чи матері, проте фігура батька більше впливає на розвиток загального показника психосоматичної компетентності, а матері - на самооцінку дитини молодшого шкільного віку. При одночасному впливі батька й матері на розвиток тілесного Я молодшого школяра пріоритет надається батькові, як це в подальшому зберігається й у підлітковому віці (Туркова, 2019). А результати емпіричного дослідження когнітивно-емоційних аспектів тілесного Я членів сім’ї дитини-підлітка встановили взаємозв'язок тілесного локусу контролю з психосоматичною компетентністю й дали змогу виявити, що в розвитку тілесного Я підлітка значну роль відіграє особа батька. Цікавим виявилося те, що спільна поведінка батьків дійсно виступає своєрідним міксом уособленої поведінки подружньої пари. Провівши паралель із поведінкою підлітка, можемо побачити, що адаптивні й відносно адаптивні механізми усереднено відображають поведінку батька й матері, проте неадаптивні механізми схожі на спільну стратегію батьків. Це означає, що у конфліктних ситуаціях батьки й дитина демонструють однакові неадаптивні копінги, і це призводить до патової ситуації непорозуміння (Туркова \& Ляса, 2019).

Урахувавши показник гестаційної домінанти матері під час вагітності на розвиток тілесного Я дитини, у нашому ретроспективному опитуванні жінок було виявлено, що чинником, який сприяє зростанню показника діалогічності тілесного Я матері, є оптимальний тип психологічно-

(C) Turkova Daria

DOI (article): https://doi.org/10.32626/2227-6246.2020-49.342-362 
го компонента гестаційної домінанти, що характеризується відповідальним, без зайвої тривоги, ставленням до вагітності, зрілими подружніми взаєминами, бажаною вагітністю. Оптимальний тип сприяе формуванню гармонійному сімейному вихованню дитини. Нами було підтверджено, що задля створення оптимальних умов розвитку тілесного Я дитини необхідно враховувати психосоматичні особливості матері під час вагітності, адже при роботі з родиною дошкільника актуальний стан матері скоріше наслідок, ніж причина (Туркова, 2019).

\section{Висновки}

Отже, враховуючи результати нашого аналітичного дослідження й попередньо отримані емпіричні результати, можемо дійти таких висновків щодо розуміння тріадних взаємин у родині в контексті розвитку тілесного Я.

1. Під тріадою розуміється система «батько - мати - дитина», яка функціонує за законами теорії сімейних систем i, відповідно, будь-які психотерапевтичні втручання повинні здійснюватися на засадах системної сімейної психотерапії.

2. Розвиток тілесного Я дитини закладається ще на перинатальній стадії розвитку в контексті формування діади «мати - дитина». Якість цього процесу залежить від психологічного показника гестаційної домінанти матері під час вагітності й ролі батька, який продовжує виступати у цей період частиною системи «чоловік - дружина» .

3. Народження дитини призводить родину до чергового стресового періоду, успішне подолання якого має створити тріадні взаємини, у яких із новими ролями батька й матері подружжя не втрачає інтимний контакт один з одним у якості чоловіка та дружини.

4. На всіх етапах функціонування родини, в тому числі під час вагітності й у подальшому, важлива та незамінна роль батька для гармонійного розвитку дитини загалом і тілесного Я зокрема. Діада «мати - дитина» рівнозначна діаді (C) Turkova Daria

DOI (article): https://doi.org/10.32626/2227-6246.2020-49.342-362 
«батько - дитина», в разі надання можливості батькові долучитися до процесу догляду та виховання дитини (важливим є навіть тактильний контакт одразу після народження).

5. Починаючи з молодшого шкільного віку й до підліткового включно - посилюється референтність особи батька стосовно матері в контексті розвитку тілесного Я дитини.

Зазначені висновки спонукають нас бачити у перспективі подальших досліджень розробку й апробацію системи розвитку тілесного Я у тріадних взаєминах родини («батько - мати - дитина») залежно від етапу онтогенезу дитини.

\section{Література}

Варга А. Я. Введение в системную семейную психотерапию. Москва : Когито-Центр, 2011. 182 с.

Горшкова Н. М. Особенности образа тела у детей старшего дошкольного возраста, воспитывающихся в условиях отцовской депривации в разные периоды детства: автореф. дис. ... канд. психол. наук: 19.00.13. Москва : Московский городской психолого-педагогический университет, 2013. 26 с.

Горшкова Н. М., Филиппова Е. В. Особенности образа тела у детей дошкольного возраста, воспитывающихся без отца в различные периоды детства. Психологическая наука и образование. 2013. № 3. С. $66-77$.

Перинатальная психология и психиатрия: В 2 т. / под ред. Н. Н. Володина, П. И. Сидорова. Москва : Академия, 2009. Т. 2. 256 с.

Седих К. В. Формування психосоматичної компетентності в психологічному консультуванні подружніх пар. Психологія $і$ особистість. 2017. № 2 (12). C. 158-167.

Туркова Д. М. Особливості розвитку тілесного Я молодшого школяра у контексті сімейних відносин. Психологічний часопис: Збірник наукових пращь / за ред. С. Д. Максименка. Київ : Інститут психології імені Г. С. Костюка НАПН України, 2019. № 10. Вип. 5. C. $156-167$.

Туркова Д. М. Психологічний компонент гестаційної домінанти як предиктор психосоматичної кризи. Особистість у кризових уловах та критичних ситуаціях життя: Матеріали V Міжнародної науково-практичної конференції (28 лютого - 1 березня 2019 року, ж. Сули). Суми : Вид-во СумДПУ імені А. С. Макаренка, 2019. C. 237-240.

(C) Turkova Daria

DOI (article): https://doi.org/10.32626/2227-6246.2020-49.342-362 
Туркова Д. М., Ляса М. В. Когнітивно-емоційні аспекти тілесного Я членів сім'ї. Психологічний часопис: Збірник наукових праць / за ред. С. Д. Максименка. Київ : Інститут психології імені Г. С. Костюка НАПН України, 2019. № 9. Вип. 5. С.118-130.

Фисун Е. В. Брак и дети. Системная психотерапия супружеских пар / сост. А. Я. Варга. Москва : Когито-Центр, 2017. 342 с.

Cabrera, N. J., Tamis-LeMonda, C. S., Bradley, R. H., Hofferth, S., \& Lamb, M. E. (2000). Fatherhood in the twenty-first century. Child Development, 71 (1), 127-136.

Favez, N., \& Frascarolo, F. (2011). Le développement des interactions triadiques mère-père-enfant [The development of mother-father-child triadic interactions]. Devenir, 23 (4), 359-377.

Favez, N., Frascarolo, F., \& Tissot, H. (2017). The family alliance model: a way to study and characterize early family interactions. Frontiers in Psychology, (Vol. 8). URL : https://doi.org/10.3389/fpsyg. 2017.01441 .

Lamb, M. E. (2010). The role of the father in child development. 5th Edition. Cambridge : John Wiley \& Sons Inc. $672 \mathrm{p}$.

Levin, K., \& Currie, C. (2010). Family structure, mother-child communication, father-child communication, and adolescent life satisfaction: A cross-sectional multilevel analysis. Health Education, 110 (3), $152-168$.

Lindsey, E., \& Caldera, Y. (2006). Mother - Father - Child Triadic Interaction and Mother - Child Dyadic Interaction: Gender Differences Within and Between Contexts. Sex Roles, 55 (7-8), 511-521.

Simonelli, A., Parolin, M., Sacchi, C., De Palo, F., \& Vieno, A. (2016). The role of father involvement and marital satisfaction in the development of family interactive abilities: A multilevel approach. Frontiers in psychology, 7, 1725. URL : https://doi.org/10.3389/ fpsyg.2016.01725.

Venturelli, E., Cabrini, E., Fruggeri, L., \& Cigala, A. (2016). The study of triadic family interactions: the proposal of an observational procedure. Integrative Psychological and Behavioral Science, 50, 655683.

\section{References}

Varga, A. Ya. (2011). Vvedeniie $v$ sistemnuiu semeinuiu psikhoterapiiu [Introduction to the systemic family therapy]. Moskva : Kogito-Tsentr [in Russian].

Gorshkova, N. M. (2013). Osobennosti obraza tela u detei starshego doshkolnogo vozrasta, vospityvaiushchikhsia $\mathrm{v}$ usloviiakh ottsovskoi

(C) Turkova Daria

DOI (article): https://doi.org/10.32626/2227-6246.2020-49.342-362 
deprivatsii v raznyie periody detstva [Features of the body image of children in preschool age raised in the father's deprivation in the different periods of their childhood]. Extended abstract of candidate's thesis. Moskva : Moskovskii gorodskoi psikhologo-pedagogicheskii universitet [in Russian].

Gorshkova, N. M., \& Filippova, E. V. (2013). Osobennosti obraza tela u detei doshkolnogo vozrasta, vospityvaiushchikhsia bez ottsa v razlichnyie periody detstva [Features of the body image in preschool children raised without father in different periods of their childhood]. Psikhologicheskaia nauka i obrazovaniie - Psychological science and education, 18 (3), 66-77 [in Russian].

Volodin, N. N., \& Sidorov, P. I. (Eds.). (2009). Perinatalnaia psikhologiia i psikhiatriia [Perinatal psychology and psychiatry]. (Vol. 2.). Moskva : Akademiia [in Russian].

Sedykh, K. V. (2017). Formuvannia psykhosomatychnoi kompetentnosti v psykholohichnomu konsultuvanni podruzhnikh par [The formation of psychosomatic competence in the couple's psychological counseling]. Psykholohiia i osobystist - Psychology and personality, 2 (12), 158-167 [in Ukrainian].

Turkova, D. M. (2019). Osoblyvosti rozvytku tilesnoho Ya molodshoho shkoliara $\mathrm{u}$ konteksti simeinykh vidnosyn [The characteristics of bodily-self development at primary schoolchildren in the context of family relations]. Psykholohichnyi chasopys - Psychological journal: Collection of research papers, 10 (5), 156-167. Kyiv : Instytut psykholohii imeni H. S. Kostiuka NAPN Ukrainy [in Ukrainian].

Turkova, D. M. (2019). Psykholohichnyi komponent hestatsiinoi dominanty yak predyktor psykhosomatychnoi kryzy [Psychological component of gestational dominant as a predictor of psychosomatic crisis]. Osobystist u kryzovykh umovakh ta krytychnykh sytuatsiiakh zhyttia - Personality in crisis conditions and crisis life situations: Proceedings of the fifth International scientifical and practical conference, (pp. 237-240). Sumy : Vyd-vo SumDPU imeni A. S. Makarenka [in Ukrainian].

Turkova, D. M., \& Liasa, M. V. (2019). Kohnityvno-emotsiini aspekty tilesnoho Ya chleniv simi [Cognitive and emotional aspects of family members' bodily-self]. Psykholohichnyi chasopys - Psychological journal: Collection of research papers, 9 (5), 118-130. Kyiv : Instytut psykholohii imeni H. S. Kostiuka NAPN Ukrainy [in Ukrainian].

Fisun, E. V. (2017). Brak i deti [The marriage and children]. Sistemnaia psikhoterapiia supruzheskikh par - Systemic therapy of married couples. A. Ya. Varga (Ed.). Moskva : Kogito-Tsentr [in Russian].

(C) Turkova Daria

DOI (article): https://doi.org/10.32626/2227-6246.2020-49.342-362 
DOI: https://doi.org/10.32626/2227-6246.2020-49 2020. випуск 49

Cabrera, N. J., Tamis-LeMonda, C. S., Bradley, R. H., Hofferth, S., \& Lamb, M. E. (2000). Fatherhood in the twenty-first century. Child Development, 71 (1), 127-136.

Favez, N., \& Frascarolo, F. (2011). Le développement des interactions triadiques mère-père-enfant [The development of mother-father-child triadic interactions]. Devenir, 23 (4), 359-377 [in French].

Favez, N., Frascarolo, F., \& Tissot, H. (2017). The family alliance model: a way to study and characterize early family interactions. Frontiers in Psychology, (Vol. 8). Retrieved from https://doi.org/10.3389/ fpsyg.2017.01441.

Lamb, M. E. (2010). The role of the father in child development. 5th Edition. Cambridge : John Wiley \& Sons Inc.

Levin, K., \& Currie, C. (2010). Family structure, mother-child communication, father-child communication, and adolescent life satisfaction: A cross-sectional multilevel analysis. Health Education, 110 (3), 152-168.

Lindsey, E., \& Caldera, Y. (2006). Mother - Father - Child Triadic Interaction and Mother - Child Dyadic Interaction: Gender Differences Within and Between Contexts. Sex Roles, 55 (7-8), 511-521.

Simonelli, A., Parolin, M., Sacchi, C., De Palo, F., \& Vieno, A. (2016). The role of father involvement and marital satisfaction in the development of family interactive abilities: A multilevel approach. Frontiers in psychology, 7, 1725. Retrieved from https://doi.org/10.3389/ fpsyg.2016.01725.

Venturelli, E., Cabrini, E., Fruggeri, L., \& Cigala, A. (2016). The study of triadic family interactions: the proposal of an observational procedure. Integrative Psychological and Behavioral Science, 50 (4), 655-683.

\section{Туркова Дар'я. Тріадні взаємовідносини в родині у контексті розвитку тілесного Я}

\section{АНОТАЦІЯ}

У чій статті наведено аналітичний огляд психологічних досліджень щодо структури родин із тріадними та діадними взаємовідносинами в контексті розвитку тілесного Я. Визначено роль батька у психологічному розвитку дитини. Надано перелік психологічних показників розвитку дитини, на які впливає присутність батька або його депривація. Перелічено характеристики функціонування родини у разі появи дитини. Визна(C) Turkova Daria

DOI (article): https://doi.org/10.32626/2227-6246.2020-49.342-362 
чено оптимальні умови функціонування родини для здорового розвитку дитини й розвитку тілесного Я.

Метою публікації є систематизація теоретико-прикладних положень щодо розуміння психологічного сенсу тріади у контексті розвитку тілесного Я.

Основним методом дослідження слугував теоретичний аналіз наукової літератури, що дало змогу з'ясувати роль тріади «батько мати - дитина» у розвитку тілесного Я дитини.

Результати дослідження дали змогу визначити рівноправну роль батька стосовно матері при вихованні дитини. Також було визначено психологічні якості розвитку дитини, що потребують саме долучення батька. 3'ясовано оптимальні умови функціонування тріади в родині задля розвитку тілесного $Я$.

Висновок. Під тріадою розуміється система "батько - мати - дитина», яка функціонує за законами теорії сімейних систем. Розвиток тілесного я дитини закладається ще на перинатальній стадії розвитку в контексті формування діади "мати - дитина». Народження дитини призводить до чергового стресового періоду в родині, успішне подолання якого має створити тріадні взаємини, у яких з новими ролями батька й матері подружжя не втрачає інтимний контакт один з одним у якості чоловіка та дружини. На всіх етапах функціонування родини, в тому числі під час вагітності й у подальшому, важлива і незамінна роль батька для гармонійного розвитку дитини загалом і тілесного Я зокрема. Діада "мати - дитина» рівнозначна діаді "батько - дитина», в разі надання можливості батькові долучитися до прочесу догляду та виховання дитини.

Ключові слова: тріадні взаємовідносини, діадні взаємовідносини, батьківство, сімейна система, розвиток тілесного Я.

Туркова Дарья. Триадные взаимоотношения в семье в контексте развития телесного Я

\section{АННОТАЦИЯ}

В данной статье предоставлен аналитический обзор психологических исследований относительно структуры семей с триадными и диадными взаимоотношениями в контексте развития телесного Я. Определена роль отца в психологическом развитии ребенка. Предоставлен перечень

(C) Turkova Daria

DOI (article): https://doi.org/10.32626/2227-6246.2020-49.342-362 
психологических показателей развития ребенка, на которые влияет присутствие отца или его депривация. Описаны характеристики функционирования семьи при появлении ребенка. Определены оптимальные условия функционирования семьи для здорового развития ребенка и развития телесного Я.

Целью публикации является систематизация теоретико-прикладных положений относительно понимания психологического смысла триады в контексте развития телесного Я.

Основным методом исследования служил теоретический анализ научной литературы, что дало возможность выяснить роль триады «отец-мать - ребенок» при развитии телесного Я ребенка.

Результаты исследования дали возможность определить равноправную роль отца по отношению к матери при воспитании ребенка. Также были определены психологические качества развития ребенка, что требуют именно участия отца. Выяснены оптимальные условия функционирования триады в семье для развития телесного Я.

Вывод. Под триадой понимается система "отец-мать-ребенок», которая функционирует за законами теории семейных систем. Развитие телесного Я ребенка закладывается еще на перинатальной стадии развития в контексте формирования диады «мать - ребенок». Рождение ребенка приводит к очередному стрессовому периоду в семье, успешное преодоление которого должно создать триадные взаимоотношения, в которых с новыми ролями отца и матери супружеская пара не теряет интимный контакт друг с другом в качестве мужа и жены. На всех этапах функционирования семьи, в том числе во время беременности и в дальнейшем, важна и незаменима роль отиа для гармонического развития ребенка вообще и телесного Я в частности. Диада «мать - ребенок» равнозначна диаде "отец - ребенок», в случае предоставления возможности отиу приобщиться к процессу ухода и воспитания ребенка.

Ключевые слова: триадные взаимоотношения, диадные взаимоотношения, отцовство, семейная система, развитие телесного Я.

Original manuscript received April 20, 2020

Revised manuscript accepted May 29, 2020

(C) Turkova Daria

DOI (article): https://doi.org/10.32626/2227-6246.2020-49.342-362 